Roy, H., and Moudrianakis, E. N., Proc. natn. Acad. Sci. U.S.A., 68, 2720 (1971).

4 Myers, T. C., Nakamura, K., and Flesher, J. W., J. Am. chem. Soc., 85, 3292, (1963).

5 Bekina. R. M., and Krasnovskii, A. A., Biokhimiya, 33, 178 (1968).

Horak, A., and Hill. R. D., Plant Physiol., 49, 365 (1972).

7 Mackinney, G., J. hiol. Chem., 140, 315 (1941).

"Larsen, M., Willett, R., and Yount, R. G., Science, 166 (1969).

'Avron, M., Anal. Biochem., 2, 535 (1961).

10 Forti, G., Rosa, L., and Garlaschi, F., FEBS Lett., 27, 23 (1972).

1 McPhee, J., and Brody, S. S., Proc. natn. Acad. Sci. U.S.A., 70, $50(1973)$

12. Hilborn, D. A., and Hammes, G. G., Biochemistry, 12, 983 (1973).

13 Harris, D. A., Rosing, J., Van De Stadt, R. J., and Slater, E. C., Biochim. biophys. Acta, 314, 149 (1973).

\section{Sap stain in Antiaris africana, an economically important tropical white wood}

MANY countries lose thousands of pounds annually through natural staining of valuable wood. Usually the organism which causes staining is the fungus Botryodiplodia theobromae Pat. Field and laboratory experiments have shown that Antiaris africana becomes stained blue within $4 \mathrm{~d}$ of felling.2.3. The fungus enters the cut surface of the wood through the vessels and within $2 \mathrm{~d}$ heavily colonises the surrounding vasicentric parenchyma cells. Infection of ray cells occurs through the vasicentric parenchyma cells ${ }^{1}$. The fungus has two types of hyphae: some are stout and brown in colour, others are thin and hyaline. The brown hyphae are predominantly found in vessels, tracheids and fibres (Fig. 1), whereas the parenchyma cells are heavily infected by the hyaline hyphae.

It is significant that not all fungi to which cut logs of $A$. africana are exposed gain entrance to the wood through vessels. Phialophora fastigiata, a sap stainer with a tendency to behave like a soft-rot fungus enters the wood through the ray parenchyma cells from which it ramifies into the vasicentric parenchyma cells. The vessels are infected through

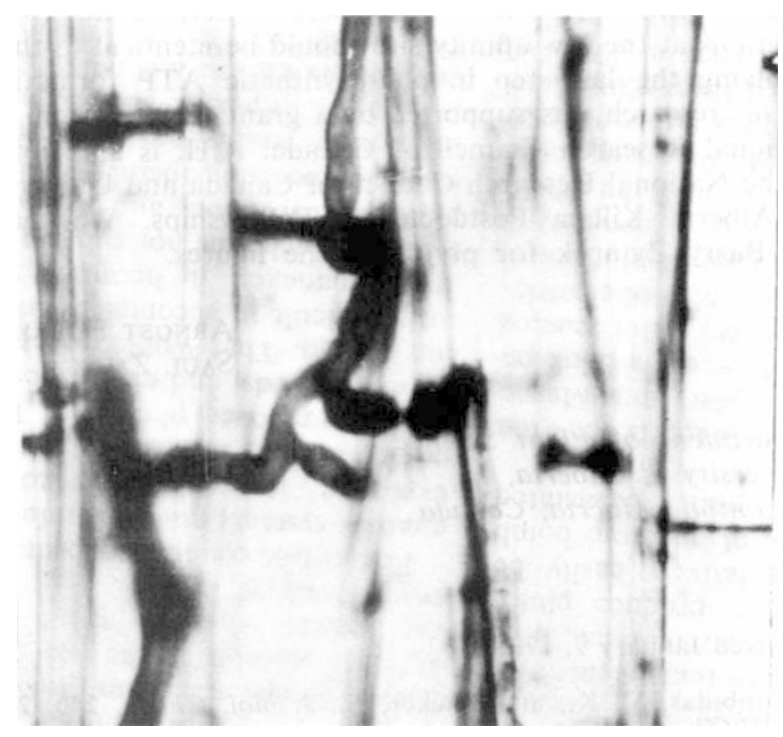

Fig. 1 Brown hyphae in vessels of Antiaris africana. $\times 480$. parenchyma cells. Within $14 \mathrm{~d}$ of infection, the fungus successfully digests the secondary wall of the fibres, creating cavities in oblique, transverse and longitudinal directions. Rhinocladiella atrovirens, a sap stainer, and Chaetomium globosum infect the wood through the rays and the vasicentric parenchyma cells.

Shoots of $A$. africana were exposed to ${ }^{14} \mathrm{CO}$, for $45 \mathrm{~min}$ three times a week for 2 weeks and then cut into small logs. The cut surface of each log was sprayed with spores of $B$. theobromae and the fungus was isolated from the logs after $7 \mathrm{~d}$. The fungus was extracted with boiling ethanol and the ethanol-insoluble residue was wet-combusted ${ }^{*}$. Radioactivity was detected especially in the enthanol extract of the isolated fungus, providing direct evidence that $B$. theobromae uses food reserves of the xylem. There is also experimental evidence that there is no correlation between the severity of the blue-stain infection and the concentration of carbohydrate in the xylem 3 . It is, however, essential for carbohydrate to be present in the xylem for successful establishment of the fungus. Experiments on the food reserves of the xylem of $A$. africana show that it is rich in various carbohydrates. Kozlowski and Keller ${ }^{\text {i }}$ have reported that carbohydrates are stored in the living parenchyma cells of the xylem of trees. It is, therefore, most probable that the hyaline hyphae predominantly found in the living parenchyma cells of the wood of $A$. africana are nutritional in function.

Several methods have been suggested for the control of sap blue stain fungi-.,. . Eight antitranspirants have recently been tried in the laboratory on germination of spores of $B$. theobromae, and in the field on the control of blue stain in $A$. africana, and four have been very effective. Spores were mounted in various concentrations of antitranspirants and incubated at $100 \%$ relative humidity. Percentage germination was counted over a period of $24 \mathrm{~h}$. In the field experiments conducted during the rainy season when the incidence of blue-stain in $A$. africana is known to be heaviest", cut surfaces of logs were dipped in antitranspirants. Needle Fast, Spruce Seal and Vapor Gard (1-5\%) Wilt Pruf $(5-25 \%)$ prevented spore germination and significantly reduced blue stain infection of wood left in the forest for 4 weeks. Each of the four antitranspirants significantly reduced water loss from the cut surfaces of the logs. There was no infection when the water content of the wood was more than $50 \%$.

These observations indicate that successful control of blue stain of wood should be aimed at either depleting the food reserves in the wood or using chemicals that will prevent rapid water loss from cut surfaces of logs

I am grateful to Dr J. F. Levy of Imperial College of Science and Technology, London who supplied me with $R$. atrovirens, $C$. globosum and $P$. fastigiata.

\section{O. Olofinboba}

Department of Botany,

University of Ibadan,

Ibadan, Nigeria

Received March 8, 1973.

Olofinboba, M. O., and Lawton, J. R. S., Inst. W. Sci., 21, 6 (1968).

2 Momoh, Z. O., Technical note 36 (Dept. of Forest Research, Ibadan, 1966).

Olofinboba, M. O., Nig. J. For., 2, 54 (1972).

van Slyke, D. D.. and Folch, J. J., J. Biol. Chem., 136, 509 (1940).

"Olofinboba, M. O., Ann. Bot., 33, 339 (1969).

Kozlowski, T. T., and Keller, T., Bot. Rev., 32, 294 (1966).

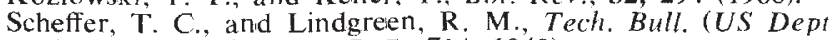
of Agric., Washington, D.C. 714,1940 ).

${ }^{*}$ Cartwright, K. S. C.. and Findlay, W. P. K., Decay of Timber and its Prevention (HMSO, London, 1958). 